\title{
EVALUATION OF THE CHARACTERISTICS AND AGRONOMIC VALUE OF FINNISH TAMMISTO MEADOW FESCUE (FESTUCA PRATENSIS HUDS.) SEED GROWN IN THE USA
}

\author{
Eero Valle ${ }^{1}$, Otto Valle ${ }^{1}$ ) $†$, Kirsti ÄyräväInen ${ }^{1}$ ) and C. S. Carrison ${ }^{2}$ ) \\ Department of Plant Husbandry, University of Helsinki ${ }^{1}$ )
}

Plant Science Research Division, Agricultural Research Service, U. S. Department of Agriculture")

Received February 1, 1972

\begin{abstract}
Seed of the Finnish meadow fescue cultivar Tammisto was grown up to four successive generations at Prosser, Washington and Shafter and Tehachapi, California, USA. Each seed lot was evaluated for its characteristics in Finland by single-plant tests in which the basic seed lot for all the American increases served as standard. - Average seed yields ranged from 540 to $660 \mathrm{~kg} / \mathrm{ha}$ at the three American trial locations. No remarkable significant differences occurred in seed yields as the generation of increase advanced from the first to the fourth. - The evaluated trials indicate that there was a substantial stability in the response of the cultivar to the environmental conditions at each seed production location. The greatest changes were found to have occurred in the Shafter lots, whereas those from Prosser and Tehachapi showed minor shifts and resembled each other quite closely. The clearest shifts occurred in the rate of development. All lots showed an increase in the proportion of plants headed in the first season, and in the second season they likewise became headed earlier than the Finnish basic lot. The shift towards earliness took place mostly in the first generation, although a continuing shift towards earlier average date of heading was still observed in the third generation. The two characteristics indicating heading were highly significantly correlated with each other but not with any of the six other characteristics observed. Seed from all the three American experimental locations gave rise to populations with noticeably reduced proportions of prostrate-growing plants. This change usually took place during the first generation of increase. The third and fourth-generation lots from Prosser and Shafter overwintered distinctly less well than the first and second-generation or basic seed lots. In other characteristics shifts were minor or non-existent. - Within the material from each seed production location evaluation trials showed positive correlations between each of the following characteristics: winter survival, number of stalks/plant (2nd year), plant height and fresh weight. Partial correlations calculated from the entire US material showed that winter survival and fresh weight were positively correlated with stalk number and plant height; between the two latter characteristics there was a significant negative correlation. - Forage production trials revealed no differences between the lots in terms of total forage yield and winter survival, not even after three to four generations of seed increase in the USA.
\end{abstract}

In many countries seed production of forage crop cultivars is seriously restricted by unfavourable weather conditions during flowering, seed ripening and harvest with the

This study was supported by grant No. FG-Fi-144 of P.L. 480 curriencies from the U. S. Department of Agriculture. 
consequence of need for seed imports. Past experiences have shown, however, that in perennial forage crops foreign seed usually represents plant material poorly adapted to the growing conditions in the importing country. This unfortunate situation has stimulated efforts to multiply seed of superior cultivars outside their region of origin, in areas best suited for high-quality seed production (VAlle \& CARrison 1963). Before starting largescale seed production of cross-pollinated species it is essential to determine the extent the most desirable varietal characteristics may change during seed multiplication in foreign environments. Even in the region of origin each seed harvest puts the stability of the cultivar into hazard, and an even greater risk is incurred when seed production is transferred to extraordinary environments. Selection pressures due to such factors as temperature, day-length, diseases and insects may tend to eliminate certain types from the plant population thus changing the identity of the cultivar in regard to some valuable qualities.

The work to be presented here was part of a comprehensive research project dealing with seed production of Finnish grass and clover cultivars in the USA. The results are being published separately for each species studied. This extensive project, in which grasses were included since 1965, was financed by grants from the Agricultural Research Service, US Department of Agriculture, of P.L. 480 currencies. Progress towards the objectives of this project was only possible through intimate and fruitful cooperation between American and Finnish research workers. Seed production plots in Prosser, Washington and Shafter and Tehachapi, California, which provided seed material for evaluation trials in Finland, were under the supervision of Mr. C. S. Carrison, USDA, Beltsville, Maryland. Shortly before the termination of the project the working team was sadly and unexpectedly deprived of its principal investigator Prof. Otto Valle by his sudden death in November 1969.

The seed lots produced in the USA were evaluated for their various characteristics in spaced-plant trials in Finland. In 1965 - 66 the trials were situated at the Department of Plant Husbandry, Agricultural Research Centre, Tikkurila, and in 1966-70 at the Department of Plant Husbandry of the University of Helsinki, Viik Experimental Farm, Helsinki. Forage production trials were conducted at Viik as well as on the Experimental Farm of Länsi-Hahkiala at Hauho (South Finland).

The meadow fescue cultivar studied was Tammisto released by Prof. Otto Valle in 1928. It originates from a relatively homogeneous local strain from East-Finland. Its most distinguishing characteristics are relatively late heading, prostrate growth habit prior to heading, and excellent winter-hardiness. Its genetical background is wider than that of the more recent synthetic varieties, resulting in a greater population plasticity.

\section{Geographical and meteorological data}

The experimental seed production of Tammisto meadow fescue in the USA was carried out in conditions which differed greatly from those in its region of origin (Table 1). Two of the trial locations, Shafter and Tehachapi, situated close to each other on approximately the same latitude $\left(35^{\circ} \mathrm{N}\right)$, provided material for interesting comparison as both have the same daylength but strongly different thermal conditions; in Shafter, at an elevation low above the sea, the mean temperature is much higher than in Tehachapi, situated in a mountainous region. 
Table 1. Geographical and meteorological data for the locations producing Tammisto meadow fescue.

\begin{tabular}{|c|c|c|c|c|c|c|c|}
\hline \multirow{4}{*}{ Location } & \multirow{4}{*}{$\begin{array}{c}\text { Latitude } \\
\text { North }\end{array}$} & \multirow{4}{*}{$\begin{array}{c}\text { Elevation, } \\
\text { m }\end{array}$} & \multirow{4}{*}{$\begin{array}{l}\text { Length longest } \\
\text { day in June } \\
\text { h.min. }\end{array}$} & \multicolumn{4}{|c|}{ Long-term } \\
\hline & & & & \multicolumn{2}{|c|}{ Precipitation } & \multicolumn{2}{|c|}{ Temperature } \\
\hline & & & & \multicolumn{2}{|c|}{$\mathrm{mm}$} & \multicolumn{2}{|c|}{${ }^{\circ} \mathrm{C}$} \\
\hline & & & & Annual & May-Sept. & January & July \\
\hline Tikkurila, Finland & $60^{\circ} 18^{\prime}$ & 20 & 18.57 & 655 & 304 & -6.5 & 17.0 \\
\hline Prosser, Wash. & $46^{\circ} 15^{\prime}$ & 253 & 15.45 & 191 & 50 & -1.2 & 21.6 \\
\hline Shafter, Calif. & $35^{\circ} 23^{\prime}$ & 107 & 14.32 & 159 & 10 & 6.5 & 27.8 \\
\hline Tehachapi, Calif. & $35^{\circ} 8^{\prime}$ & 1212 & 14.30 & 262 & 28 & 4.1 & 22.4 \\
\hline
\end{tabular}

Table 2. Weather conditions at Tikkurila, Finland, May-October 1965 - 70.

\begin{tabular}{|c|c|c|c|c|c|c|c|}
\hline \multirow[t]{2}{*}{ Month } & \multirow{2}{*}{$\begin{array}{c}\text { Long-term } \\
1931-60\end{array}$} & \multicolumn{6}{|c|}{ Deviation } \\
\hline & & 1965 & 1966 & 1967 & 1968 & 1969 & 1970 \\
\hline & & & Aver: & temperat & ${ }^{\circ} \mathrm{C}$ & & \\
\hline May & 9.3 & -2.5 & 0.1 & 0.6 & -1.6 & -0.6 & 0.2 \\
\hline June & 14.3 & 0.8 & 2.6 & -0.6 & 2.3 & 1.3 & 2.4 \\
\hline July & 17.0 & -2.6 & 0.6 & -0.3 & -1.8 & -0.5 & -0.6 \\
\hline August & 15.4 & -1.3 & -1.0 & 0.6 & 0.8 & 0.7 & 0.0 \\
\hline September & 10.4 & 2.1 & -1.6 & 2.2 & 0.3 & -0.5 & 0.4 \\
\hline October & 5.1 & 0.3 & 0.0 & 3.5 & 2.4 & 0.1 & -1.0 \\
\hline \multirow[t]{2}{*}{ May-Oct. } & 11.9 & -0.5 & 0.1 & 1.0 & 0.4 & 0.1 & 0.2 \\
\hline & \multicolumn{7}{|c|}{ Precipitation $\mathrm{mm}$} \\
\hline May & 40 & -18 & -26 & 13 & 45 & 1 & -15 \\
\hline June & 47 & -4 & -24 & -28 & -11 & -30 & -35 \\
\hline July & 73 & 30 & -9 & -34 & -5 & -10 & 47 \\
\hline August & 75 & 7 & -21 & 32 & -23 & -47 & -44 \\
\hline September & 69 & 16 & 3 & 6 & -22 & 26 & 10 \\
\hline October & 70 & -24 & -11 & 82 & 21 & -18 & 42 \\
\hline May-Oct. & 374 & 7 & -88 & 71 & 5 & -78 & 5 \\
\hline
\end{tabular}

The monthly mean temperatures of the growing season in Finland (data from Tikkurila) varied rather little during the experimental period (Table 2). Rainfall was more variable, although every year the total amount of precipitation was large enough to allow normal growth and development of the grasses.

\section{Seed production in the USA}

Tammisto meadow fescue was grown for seed in the USA in 1960 - 68 with the main aim of obtaining seed material for the Finnish evaluation trials. Since all the American locations for this production were in semi-arid areas where summer rainfall is scare or inadequate, the plantings were irrigated regularly during the period of most intense growth. 
Table 3. Data for seed increase plots of Tammisto meadow fescue in the USA.

\begin{tabular}{lccccccc}
\hline & $\begin{array}{c}\text { No. of } \\
\text { plantings }\end{array}$ & $\begin{array}{c}\text { Plant } \\
\text { height } \\
\mathrm{cm}\end{array}$ & $\begin{array}{c}\text { No. of } \\
\text { panicles } \\
/ \mathrm{m}^{2}\end{array}$ & $\begin{array}{c}\text { Florets } \\
\text { producing } \\
\text { seed } \%\end{array}$ & $\begin{array}{c}\text { Seed yield } \\
\mathrm{kg} / \mathrm{ha}\end{array}$ & $\begin{array}{c}\text { 1000-seed } \\
\text { weight } \\
\mathrm{g}\end{array}$ & $\begin{array}{c}\text { Germina- } \\
\text { tion } \\
\%\end{array}$ \\
\hline Location & & & & & & & \\
Prosser & 6 & $121 \mathrm{a}$ & $546 \mathrm{~b}$ & $65 \mathrm{a}$ & $661 \mathrm{a}$ & $1.91 \mathrm{a}$ & $84 \mathrm{a}$ \\
Shafter & 7 & $124 \mathrm{a}$ & $220 \mathrm{a}$ & $71 \mathrm{a}$ & $540 \mathrm{a}$ & $1.73 \mathrm{a}$ & $88 \mathrm{a}$ \\
Tehachapi & 8 & $124 \mathrm{a}$ & $453 \mathrm{~b}$ & $60 \mathrm{a}$ & $638 \mathrm{a}$ & $1.78 \mathrm{a}$ & $87 \mathrm{a}$
\end{tabular}

Means followed by the same letter do not differ at the $5 \%$ level of probability based on the Duncan multiple range test.

The first seed crop was harvested in the year following planting year; from most plantings another seed crop was harvested in the subsequent year. Rate of sowing was $1.0-2.4 \mathrm{~kg} / \mathrm{ha}$ in Prosser, 1.5-3.4 kg/ha in Shafter, and $2.2-3.4 \mathrm{~kg} / \mathrm{ha}$ in Tehachapi except for the first-generation increase for which it was $9.0 \mathrm{~kg} / \mathrm{ha}$. In Prosser the secondgeneration increases were sown at the end of August and the others at the end of April. The time of sowing in Shafter was for the first-generation increase as early as mid-February, for the other increases beginning of October. In Tehachapi all plantings were sown in the fall, the first and second-generation increases in late September - early October, the others about one month earlier. For each particular experimental location the time of harvest varied relatively little, the difference between the earliest and latest date of harvest being not more than two weeks. The average date of harvest was earliest in Shafter (mid-June), a little later in Prosser (early July), and latest in Tehachapi (about one week later than in Prosser). Each increase was usually $200-300 \mathrm{~m}^{2}$ in size but in most cases only about half this area was harvested for seed.

Varying rates and times of seeding did not seem to affect the yield results. Some data for seed increase plots are given in Table 3. The results show that all the experimental localities were suitable for seed production of Tammisto meadow fescue. The only significant differences between the localities were found in terms of number of panicles, which was significantly lowest in Shafter. Despite great yearly fluctuations, the average seed yields were good. The most uniform results were achieved in Prosser (range $341-1121 \mathrm{~kg} / \mathrm{ha}$ ), whereas in Shafter (range 99-1465 kg/ha) and Tehachapi (86-1486 kg/ha) a few unfortunate failures were compensated by occasional very rich seed yields. In Prosser and Tehachapi the average yields of the first crop year (over $800 \mathrm{~kg} / \mathrm{ha}$ ) were conspicuously higher than those of the second year $(300 \mathrm{~kg} / \mathrm{ha})$; the outcome in Shafter was the reverse. No appreciable variation, on the other hand, occurred between the different generations: average yields consistently exceeded $500 \mathrm{~kg} / \mathrm{ha}$.

\section{Evaluation trials in Finland}

M e t h o d s. Every seed lot produced at the different experimental locations in the USA was evaluated for its various characteristics in single-plant tests in Finland. These 
were carried out in five successive years, with one new trial being established every year. The first trial was planted in Tikkurila $\left(60^{\circ} 18^{\prime} \mathrm{N}\right)$ in 1965 , the others on the University Farm Viik $\left(60^{\circ} 13^{\prime} \mathrm{N}\right)$, c. $10 \mathrm{~km}$ from Tikkurila. The basic seed for all the American plantings, Tikkurila/60, was included in all evaluation trials as standard. The germination capacity of this lot remained stable and satisfactory over the whole experimental period, since all the necessary precautions were taken to store the seed properly. The evaluation trial planted in 1967 included a fresh Finnish lot produced in Tikkurila in 1966 from the Tikkurila/60 basic seed. This 1966 lot was later used as standard for forage production trials. In its characteristics it proved identical to the original basic seed. The Americangrown seed lots in the evaluation trials represented 1st to 4th-generation increases from Shafter, Tehachapi and Prosser. In the first two years the trials mainly consisted of 1st and 2nd-generation lots, in the following years 1st to 3rd, 1st to 4th, and 3rd to 4th-generation progenies, respectively.

The experimental material was sown in flats in greenhouse in April. The seedlings were transplanted to plastic »multipots» (diameter $3.5 \mathrm{~cm}$ ) about one month later and to the field during the month of June. This method of establishment proved successful in that it gave uniform, vigorous plants and was particularly suitable in Finnish conditions where the growing season is short. On the other hand, the longer growth period thus obtained increased the growth and development of the plants in the first season. - Row distance, as well as plant distance within a row, was $60 \mathrm{~cm}$. Each trial was set up according to randomized block design with four replications, except for the trial planted in 1969 where the number of replications was six. The total number of plants per seed lot tested usually varied between $160-192$.

In the establishing year, single-plant observations on growth habit (prostrate, intermediate, erect) were made about two months after planting. At the end of the growing season, percentages of headed plants for each lot and the numbers of headed stalks per plant were recorded based on observations of single plants. In the second year, winter survival was assessed individually after the beginning of growth in May and the date of heading was noted for each plant in June. Plant height, number of headed stalks per plant and fresh weight were usually determined in July when vegetative growth was in the final phase. Growth type observations were only made in the three first years; the other observations covered all the five experimental years.

In general, the observations and measurements on the single-plant trials were performed according to the recommendations for the O.E.C.D. scheme (1968). Date of heading, however, was denoted differently as the day when the first panicle was fully developed with at least two other emerged panicles in the same plant. Overwintering was assessed by estimating the surviving proportion of the plant. The scale was $0-5(0=$ plant completely destroyed); thus the actual overwintering percentages were obtained by multiplying the observation values by 20 . The observations of the second season on stalk numbers, plant heights and fresh weights were started in the first trial replication in the final phase of vegetative growth. For every characteristic the averages for each seed lot were calculated for each replication separately.

The experimental results were treated by the different characteristics by variance analysis followed by Duncan's multiple range test. The characteristics of the control lot showed considerable yearly variations depending on varying planting dates and weather 
conditions. To make the results of the different years comparable, the results for each seed lot in a particular trial were converted into relative values $($ control $=100)$. In some further statistical treatments these relative values were employed. Average date of heading, however, was not expressed as relative values but as deviations from normal (number of days earlier or later than the control). Figures $1-5$ illustrate results in some of the most important agronomical characteristics of the cultivar, compiled and presented by locations of seed production and by generations. Each point depicts the mean relative value for one seed lot in terms of a given characteristic in one year. Any particular seed lot could be included in a number of trials, the results of which are presented separately. Thus for instance the values for the first generation from each particular location are derived from four years' results for one particular lot. Any particular second or third-generation seed lot from any of the locations was tested in three or four trials. The figures thus give an indication of the yearly variations in the different characteristics of a given lot as compared with the basic seed. They also show the linear regressions between the generations and the observation values. Since these also include the relative values for the basic seed in each particular trial, the regression coefficients are mainly indicative of trends only. The data for the seed lots produced in the USA were subjected to Duncan's multiple range test to reveal possible differences between locations and generations, the results are presented separately for each characteristic studied. - In Tables 4-14, means followed by the same letter do not differ from each other at the $5 \%$ level of probability.

\section{Results}

G r ow th t y p e. Despite the fact that planting-year observations on growth type were only made in three years (1965-67), the results for all the three locations show similar decreases in the proportions of prostrate-growing plants (Fig. 1). For the Finnish control the proportion of prostrate plants of the whole population varied considerably in the different years; in the two first years it was rather low (19\% and $16 \%$ ) but much higher $(43 \%)$ in the third year. Due to considerable dispersion of the results there were no significant differences between the locations nor between the generations (Table 4). In many of the Shafter and Tehachapi lots, however, greater changes were found than in the Prosser material. The average decrease in the proportion of prostrate types in the first-generation increases was $26 \%$ as compared to the basic seed, in the following generations $36-37 \%$.

Percentage of plants headed in the first season. This characteristic, as well as the previous one, was apparently strongly affected by date of planting and weather conditions, for the number of headed plants in the basic seed lot varied greatly from year to year (range 10-33\%). In the first season the seed lots from the USA showed a clear shift towards earlier development, which became apparent from the increased numbers of headed plants (Fig. 2). The evaluation results of 48 American-grown seed lots showed that in every single lot the proportion of headed plants was higher than in the basic seed. These shifts were most obvious in the Shafter productions (Table 5) where the differences from the basic seed were consistently significant. Many Shafter lots had $65-70 \%$ headed plants. The observation values for this characteristic were in the Shafter material three times as high as in the basic lot, in Prosser and Tehachapi materials 
Fig. 1. Relative numbers of prostrate-growing plants of Tammisto meadow fescue by seed production locations

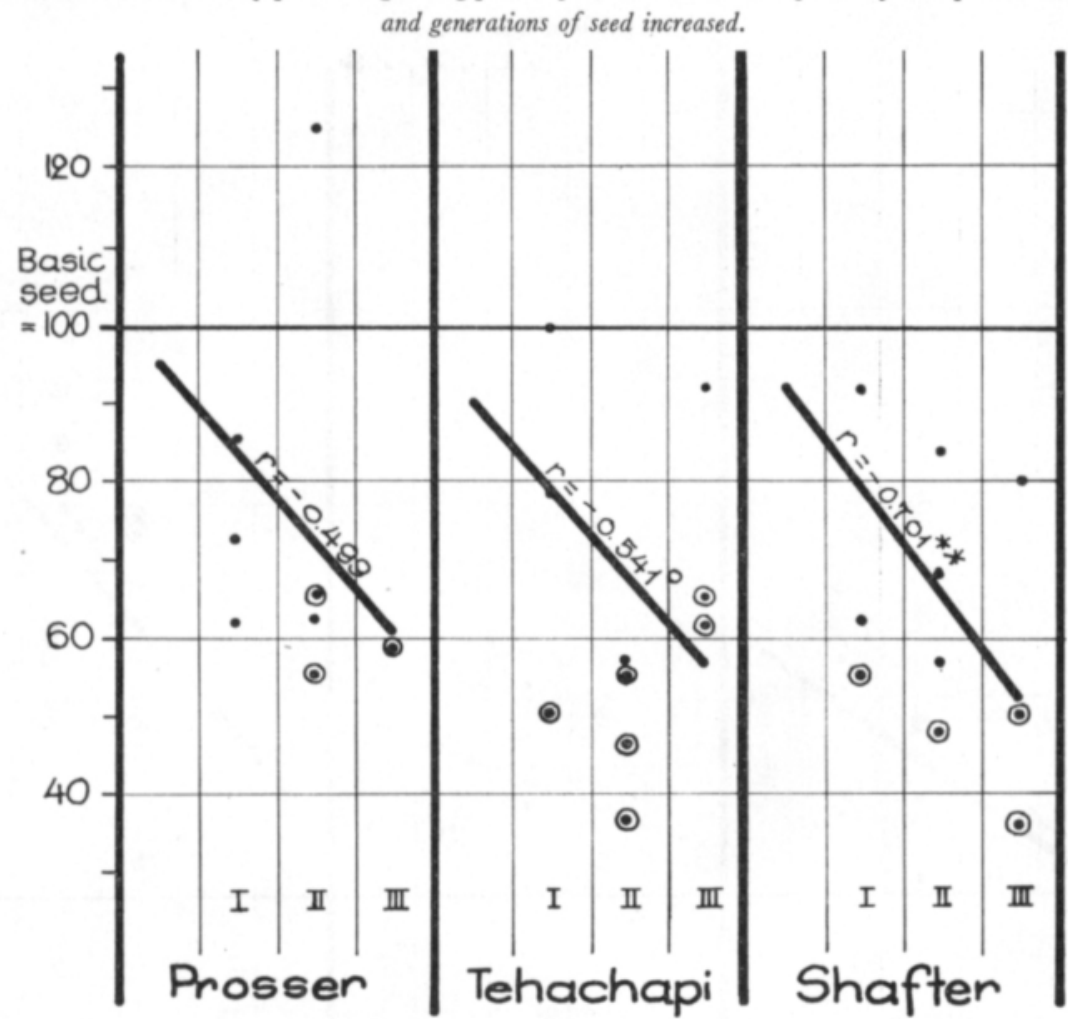

Vertically aligned points decipt the deviations of the yearly means for a given seed lot from the basic Finnish seed lot. The encircled points represent values differing from the basic seed at $5 \%$ level of significance. In the regression line the values of the basic seed lots are also calculated.

Table 4. Relative numbers (basic seed $=100$ ) of prostrate-growing plants of Tammisto meadow fescue by seed production locations and generations of seed increased.

\begin{tabular}{|c|c|c|c|c|c|}
\hline & $\begin{array}{l}\text { No. of } \\
\text { seed lots }\end{array}$ & $\begin{array}{c}\text { Prostrate } \\
\text { plants }\end{array}$ & & $\begin{array}{l}\text { No. of } \\
\text { seed lots }\end{array}$ & $\begin{array}{c}\text { Prostrate } \\
\text { plants }\end{array}$ \\
\hline Location & & & Generation & & \\
\hline Prosser & 8 & 74 a & 1 & 9 & $74 \mathrm{a}$ \\
\hline Shafter & 10 & 64 a & 2 & 12 & $64 \mathrm{a}$ \\
\hline Tehachapi & 10 & $65 \mathrm{a}$ & 3 & 7 & $63 \mathrm{a}$ \\
\hline
\end{tabular}

twice as high. The shift towards earliness occurred in the first generation and there was no further change in the following generation.

In terms of number of headed stalks/headed plant the US lots on the average did not differ from the Finnish control. The varying yearly dates of planting seemed to affect the numbers of headed stalks per headed plant much more obviously than they affected the percentage of plants headed in the first year. 
Fig. 2. Relative numbers of Tammisto meadow fescue plants headed during the first season by seed production locations and generations of seed increased.

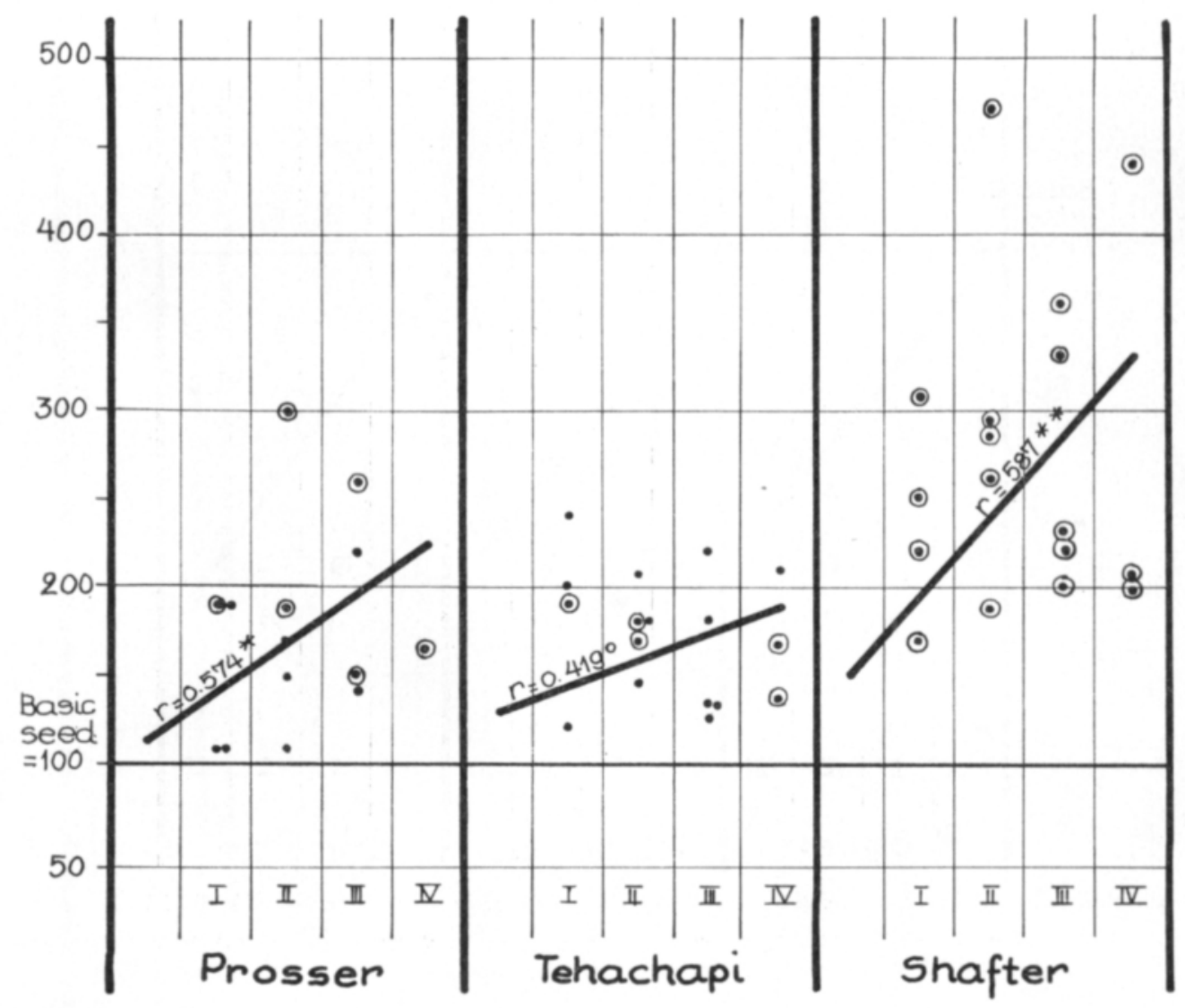

Legend as in Fig. 1.

Table 5. Relative numbers (basic seed $=100$ ) of Tammisto meadow fescue plants headed during the first season by seed production locations and generations of seed increased.

\begin{tabular}{|c|c|c|c|c|c|}
\hline & $\begin{array}{c}\text { No. of } \\
\text { seed lots }\end{array}$ & $\begin{array}{c}\text { Plants } \\
\text { headed }\end{array}$ & & $\begin{array}{c}\text { No. of } \\
\text { seed lots }\end{array}$ & $\begin{array}{c}\text { Plants } \\
\text { headed }\end{array}$ \\
\hline Location & & & Generation & & \\
\hline Prosser & 14 & $176 \mathrm{a}$ & 1 & 12 & $192 \mathrm{a}$ \\
\hline Shafter & 17 & $273 \quad b$ & 2 & 15 & 221 a \\
\hline \multirow[t]{2}{*}{ Tehachapi } & 17 & $175 \mathrm{a}$ & 3 & 14 & 209 a \\
\hline & & & 4 & 7 & 209 a \\
\hline
\end{tabular}

Winter survival. One of the most important agronomical qualities of perennial forage crops adapted to northern conditions is winter-hardiness. Seed production of Finnish Tammisto meadow fescue at different locations in the USA was in some cases found to impair the winter-hardiness of the cultivar quite markedly, whereas the Finnish lot over- 
Fig. 3. Relative winter survival of Tammisto meadow fescue after the first winter by seed production locations and generations of seed increased.

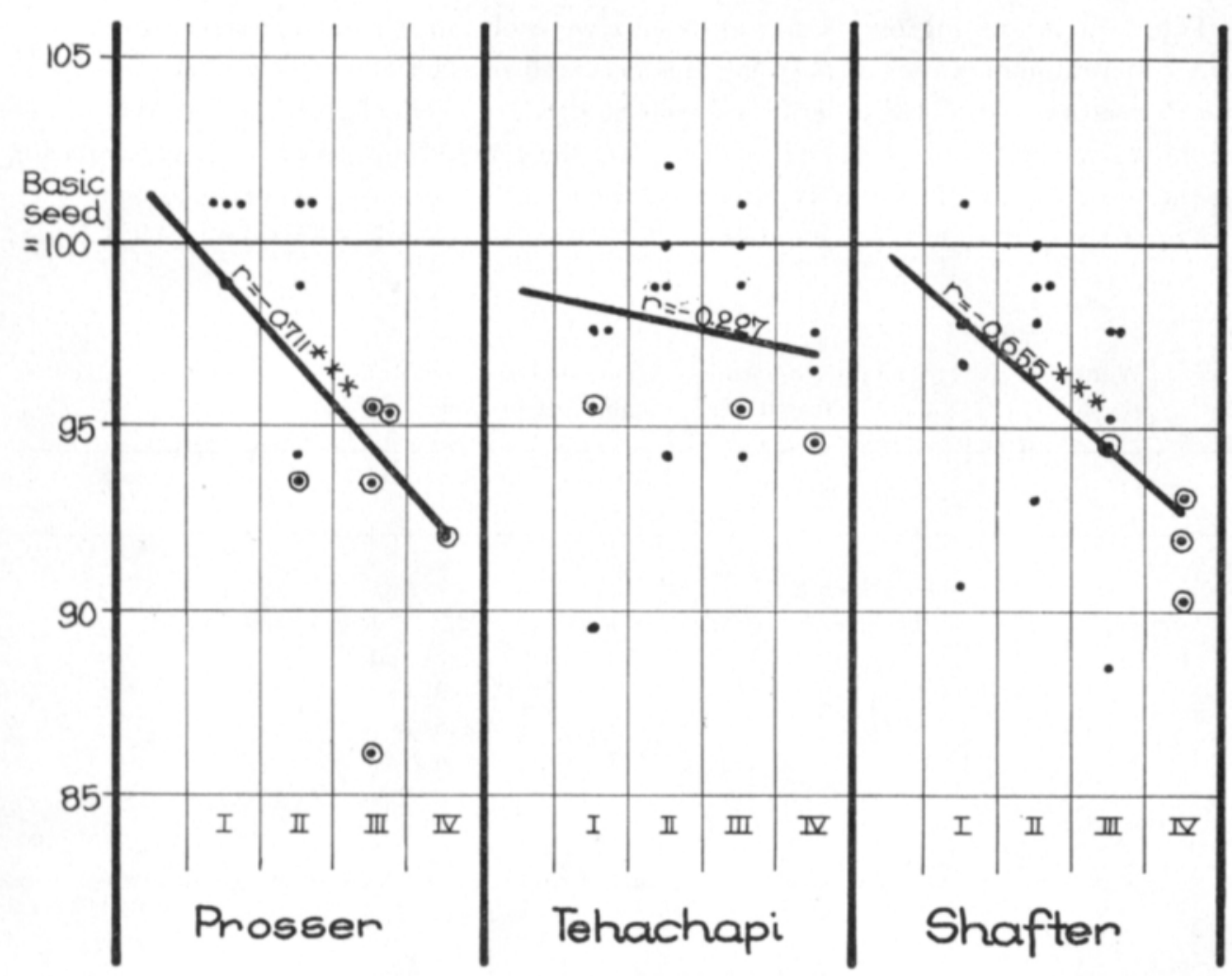

Legend as in Fig. 1 .

Table 6. Relative winter survival (basic seed $=100$ ) of Tammisto meadow fescue after the first winter by seed production locations and generations of seed increased.

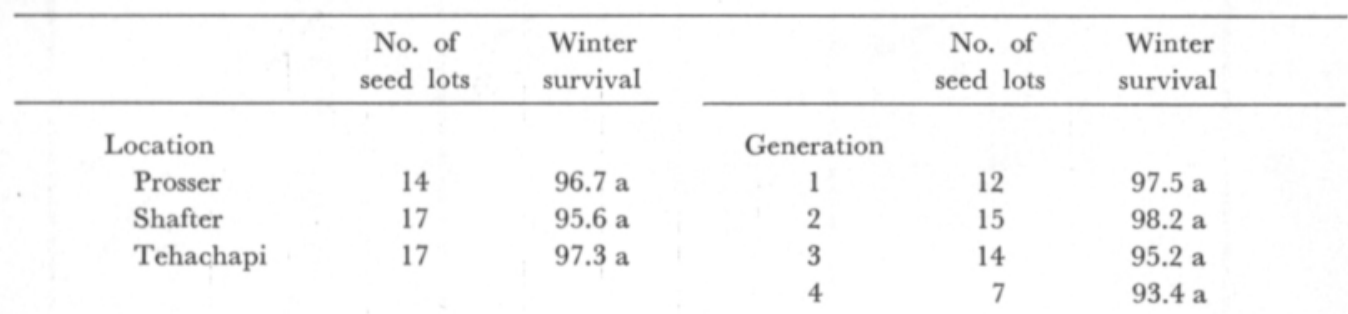

wintered successfully $(87-94 \%)$ in every trial. The loss in winter-hardiness was most obvious in the lots obtained from the third and fourth-generation increases in Prosser and Shafter (Fig. 3), but there were no significant differences due to location of production (Table 6). Similarly, the differences between the generations were statistically insignificant 
but gave the impression, however, that the third and especially the fourth generation overwintered less well than the first and the second.

The most interesting overwintering results were obtained from a trial comprising as many different generations as possible; this occurred in 1968 when 1st to 3rd generations from Prosser and 1st to 4th generations from Shafter and Tehachapi were included in one and the same trial (Table 7). The results confirm the general impression that overwintering was the more impaired, the more advanced the generation of seed increase.

Average date of heading in the second season. All US lots

Table 7. Winter survival of Tammisto meadow fescue after the first winter by generations of seed increased. Trial established in 1968.

\section{No. of Winter survival}

seed lots $\%$

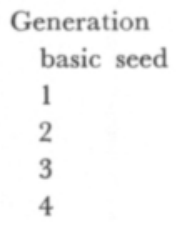

$\begin{array}{ll}1 & 93.9 \quad \mathrm{~d} \\ 3 & 92.5 \mathrm{~cd} \\ 3 & 90.9 \text { bc } \\ 4 & 89.5 \text { b } \\ 2 & 86.6 \mathrm{a}\end{array}$

Fig. 4. Average date of heading in the second season by seed production locations and generations of seed increased. Days earlier (-) or later $(+)$ than basic seed.

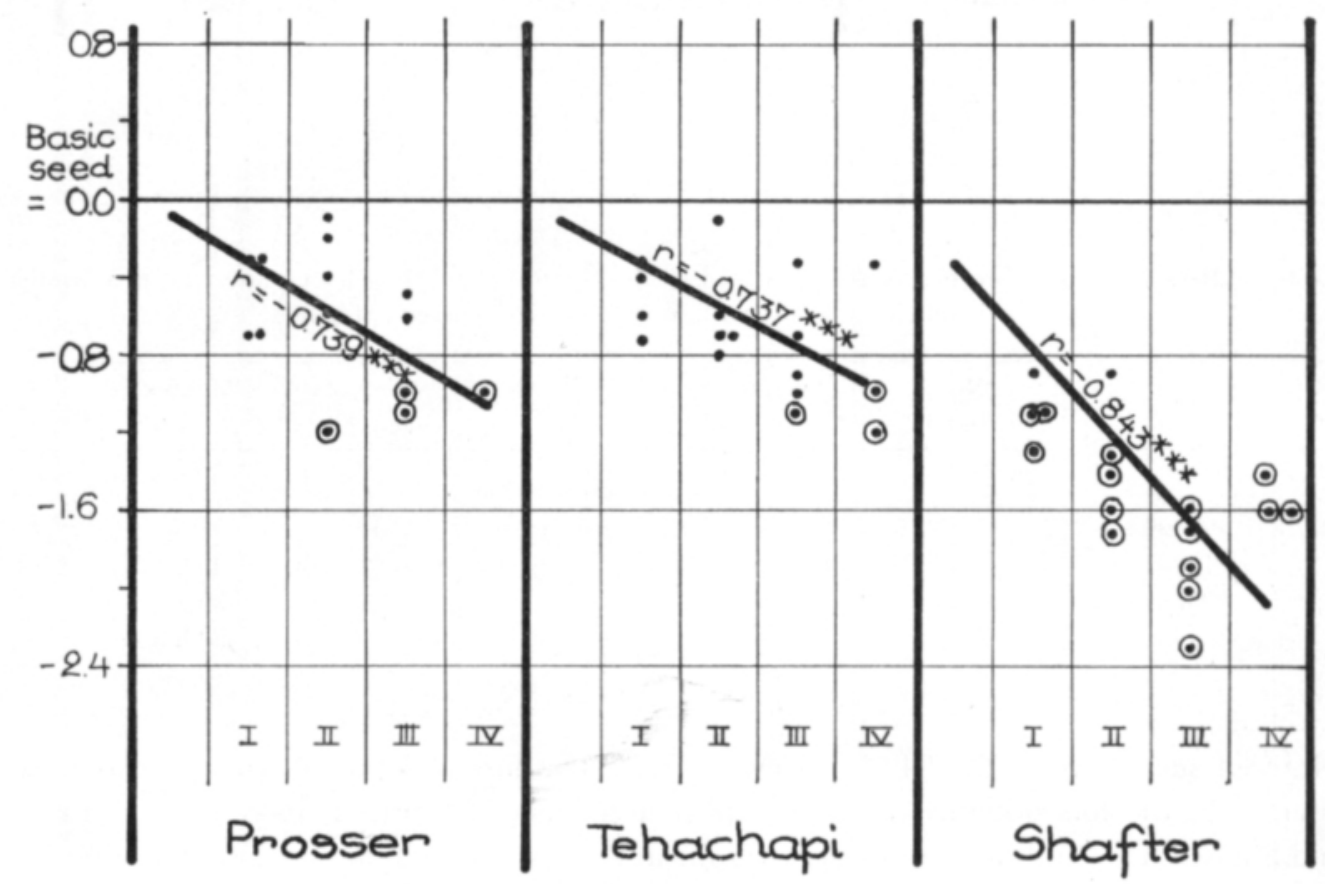

Legend as in Fig. 1. 
headed earlier than the basic lot; the first and second-generation increases from Prosser and Tehachapi, however, differed from the basic seed only slightly and insignificantly (Fig. 4). Effects of the planting date of the trial did not extend to the second year in any respect; thus the variation limits for the average date of heading for the Finnish control were as narrow as June 20-27. Heading occurred almost simultaneously in all the material. The difference between the earliest and the latest plants ranged from 9 to 20 days in the various years. Due to the uniformity of the populations most of the differences in average date of heading were statistically significant although not numerically great.

The shift towards earliness was clearest and most significant in the Shafter material (Table 8), with almost every seed lot differing significantly from the basic seed. The largest average shift was found between the basic seed and the first generation, and a further significant change in the same direction occurred in the progress from the first to the third generation but no longer in the fourth.

When these results are compared with the observations on heading in the first season (Fig. 2, Table 5), considerable similarity can be seen. The observations in both seasons revealed shifts to earliness in every seed lot produced in the USA, the most significant ones in the Shafter material.

$\mathrm{Number}$ of headed stalks per plant in second season. The number of stalks varied considerably ( $70-120$ as compared to the basic seed) in the various experimental years. The average results did not reveal any important differences between the locations (Table 9). On the other hand, slight reductions in stalk numbers

Table 8. Shifts in average date of heading of Tammisto meadow fescue (as compared to the basic seed) by seed production locations and generations of seed increased.

\begin{tabular}{|c|c|c|c|c|c|}
\hline & $\begin{array}{c}\text { No. of } \\
\text { seed lots }\end{array}$ & $\begin{array}{c}\text { Shift } \\
\text { in days }\end{array}$ & & $\begin{array}{c}\text { No. of } \\
\text { seed lots }\end{array}$ & $\begin{array}{c}\text { Shift } \\
\text { in days }\end{array}$ \\
\hline Location & & & Generation & & \\
\hline Prosser & 14 & $-0.6 \mathrm{a}$ & 1 & 12 & $-0.7 \mathrm{a}$ \\
\hline Shafter & 17 & $-1.5 \quad b$ & 2 & 15 & $-0.8 \mathrm{a} \mathrm{b}$ \\
\hline \multirow[t]{2}{*}{ Tehachapi } & 17 & $-0.7 \mathrm{a}$ & 3 & 14 & $-1.2 \quad \mathrm{c}$ \\
\hline & & & 4 & 7 & $-1.1 \quad b \mathrm{c}$ \\
\hline
\end{tabular}

Table 9. Relative number (basic seed $=100$ ) of headed stalks/plant of Tammisto meadow fescue by seed production locations and generations of seed increased.

\begin{tabular}{|c|c|c|c|c|c|}
\hline & $\begin{array}{c}\text { No. of } \\
\text { seed lots }\end{array}$ & $\begin{array}{l}\text { No. of } \\
\text { stalks }\end{array}$ & & $\begin{array}{c}\text { No. of } \\
\text { seed lots }\end{array}$ & $\begin{array}{l}\text { No. of } \\
\text { stalks }\end{array}$ \\
\hline Location & & & Generation & & \\
\hline Prosser & 14 & $96 \mathrm{a}$ & 1 & 12 & $101 \mathrm{~b}$ \\
\hline Shafter & 17 & 98 a & 2 & 15 & $102 \mathrm{~b}$ \\
\hline \multirow[t]{2}{*}{ Tehachapi } & 17 & $93 \mathrm{a}$ & 3 & 14 & 89 a \\
\hline & & & 4 & 7 & 91 a \\
\hline
\end{tabular}


were found in the third and fourth-generation lots from each location, as compared with the two earlier generations.

$\mathrm{Pl}$ a n t height. Only slight changes in plant height were observed. The relative height values for the American lots varied between 95-105 (basic seed = 100). A few third and fourth-generation lots from each location showed significant decreases in height. Seed from Shafter produced somewhat shorter plants than seed from the other locations but the differences were not significant (Table 10). The first and second-generation lots were similar to the basic seed, whereas the third generation proved slightly but insignificantly shorter. The fourth generation, however, differed significantly from all the other generations.

F resh weig h t. Determinations of fresh weights of the individual plants showed that no clear changes had taken place in the American seed lots, with only one lot differing significantly from the control. Large year-to-year variations due to weather conditions were observed: the lowest average fresh weights per plant were c. $300 \mathrm{~g}$, the highest c. $680 \mathrm{~g}$. The results for the second, and particularly for the third, generation were rather variable. The general picture of the fresh weights resembles those of the last two characteristics discussed above, stalk numbers and plant height, where the linear regressions were likewise negative for each production location ( $\mathrm{r}$ varying from -0.312 N.S. to $-0.416^{*}$ ). There were no differences in weight due to location of production, but within the locations, the third and fourth-generation lots did show slight decreases in average plant weight (Table 11).

Significance of harvest year. As stated previously (p. 282), there were considerable differences within the locations between the average seed yields of the

Table 10. Relative height (basic seed $=100$ ) of Tammisto meadow fescue by seed production locations and generations of seed increased.

\begin{tabular}{|c|c|c|c|c|c|}
\hline & $\begin{array}{l}\text { No. of } \\
\text { seed lots }\end{array}$ & Height & & $\begin{array}{c}\text { No. of } \\
\text { seed lots }\end{array}$ & Height \\
\hline Location & & & Generation & & \\
\hline Prosser & 14 & $99.6 \mathrm{a}$ & 1 & 12 & $99.9 \quad b$ \\
\hline Shafter & 17 & $98.0 \mathrm{a}$ & 2 & 15 & $99.7 \quad b$ \\
\hline \multirow[t]{2}{*}{ Tehachapi } & 17 & $99.4 \mathrm{a}$ & 3 & 14 & $98.5 \quad b$ \\
\hline & & & 4 & 7 & $96.8 \mathrm{a}$ \\
\hline
\end{tabular}

Table 11. Relative fresh weight (basic seed $=100$ ) of Tammisto meadow fescue by seed production locations and generations of seed increased.

\begin{tabular}{|c|c|c|c|c|c|}
\hline & $\begin{array}{l}\text { No. of } \\
\text { seed lots }\end{array}$ & $\begin{array}{c}\text { Fresh } \\
\text { weight }\end{array}$ & & $\begin{array}{c}\text { No. of } \\
\text { seed lots }\end{array}$ & $\begin{array}{c}\text { Fresh } \\
\text { weight }\end{array}$ \\
\hline Location & & & Generation & & \\
\hline Prosser & 14 & $100.2 \mathrm{a}$ & 1 & 12 & $102.9 \quad b$ \\
\hline Shafter & 17 & $99.5 \mathrm{a}$ & 2 & 15 & $102.5 \mathrm{~b}$ \\
\hline \multirow[t]{2}{*}{ Tehachapi } & 17 & $99.7 \mathrm{a}$ & 3 & 14 & $96.3 \mathrm{a}$ \\
\hline & & & 4 & 7 & $96.1 \mathrm{a}$ \\
\hline
\end{tabular}


first and the second harvest year (2nd and 3rd-year ley). This variation may not only be due to the effects of external conditions on yearly seed productions but may also indicate some genetic shifts in the material. It was important, therefore, in order to ensure correct interpretation of the results, to find out whether crop year had any significance upon the characteristics of seed lots of different generations. This became possible by comparing, within the limits of one evaluation trial, the 1st and 2nd-year productions of a certain seed increase plot at a given location with each other as well as with the basic seed. Such material was available for all second to fourth-generation increases from all the various locations except for the fourth generation from Prosser. The total number of such lots was 16 and they constituted one-third of the entire meadow fescue material tested.

Duncan's multiple range test revealed a total of 18 cases of significant differences between the first harvest year lots and the standard; 20 such cases were recorded for the second harvest year lots. Most of the significant differences occurred in earliness or growth type. In terms of the other characteristics significant differences were few and incidental.

When, on the other hand, first and second-year lots were compared with each other, no more than five cases of significant differences were found. One of these occurred between the second-generation lots from Tehachapi (in fresh weight), two between the second-generation lots from Prosser (in growth type and number of headed stalks/plant), and two between the fourth-generation lots from Shafter (in plant height and fresh weight). Summarized in brief, these results show that the effect of harvest year was minimal particularly on those very characteristics in which the clearest genetical shifts appeared, viz. earliness and growth type. Selection pressure from environmental conditions (edaphic, meteorological, managemental factors) thus appeared to have similar effects on both first and second harvest year lots.

Coefficients of variation. Since the evaluation observations were partly conducted by different persons and since in some of the characteristics noted there were substantial yearly variations, it was of interest to evaluate the results by determining the coefficients of variability for the different characteristics. In this way it was also hoped to check the usefulness and reliability of the observations made. The results in Table 12,

Table 12. Coefficients of variation for different characteristics of Tammisto meadow fescue in singleplant trials established in Finland in 1965-69.

\begin{tabular}{lrrrrrrrr}
\hline & \multicolumn{9}{c}{ Characteristic } & \multicolumn{1}{c}{ Y } \\
Year & 1 & 2 & 3 & 4 & 5 & 6 & 7 & 8 \\
\hline 1965 & 41.0 & 22.3 & 26.5 & 2.3 & 6.5 & 9.3 & 2.7 & 6.7 \\
1966 & 35.0 & 37.0 & 29.4 & 3.3 & 4.6 & 7.6 & 3.8 & 14.9 \\
1967 & 24.5 & 20.0 & 28.2 & 5.5 & 8.9 & 13.8 & 4.4 & 11.4 \\
1968 & & 32.6 & 42.2 & 3.3 & 5.3 & 12.1 & 4.1 & 6.2 \\
1969 & & 18.4 & 23.8 & 2.9 & 3.1 & 9.9 & 1.8 & 6.1 \\
\hline Average & 33.5 & 26.1 & 30.0 & 3.5 & 5.7 & 10.5 & 3.4 & 9.1
\end{tabular}

Characteristics: $1-3$ from observations made in planting year, $4-8$ in second year, $1=$ growth type, amounts of prostrate plants, $2=\%$ plants headed in planting year, $3=$ number of headed stalks/ headed plant (1st year), $4=$ winter survival, $5=$ aver. date of heading ( 2 nd year), $6=$ number of headed stalks/plant, $7=$ height, $8=$ fresh weight. 
presented by characteristics and trial years, show that the variation coefficients for plantingyear observations were many times greater than those for the second season. Nevertheless, changes in growth type and proportion of plants headed in the first season were in many cases great enough to produce significant differences from the basic seed (Tables 4 and 5, Figs. 1 and 2). Considering the fact that it is in these very characteristics, the cultivar Tammisto markedly differs from most other commercial meadow fescue varieties (prostrate growth habit, low percentage of plants headed in the first season), the substantial shifts found in these characteristics do partly explain the high variability. Moreover, a single-plant population generally appears far more heterogeneous in the first season than in the second, with conspicuous differences between the individual plants.

Good winter-hardiness is a quality essential to grass varieties grown in the north. The uniformly low variation coefficients for winter survival show that these observations can be considered dependable. Variation was obviously greatest in the trial established in 1967 which had to endure exceptionally severe winter conditions. The variation coefficient for plant height was low as well, but then on the other hand, changes in this characteristic were rather small. Variation in average date of heading was slightest in those years when heading occurred within a relatively long period of time, and greatest when the said period was shortest (in $19693.1 \%$ and 20 days, in $19678.9 \%$ and 9 days). Since the changes in this characteristic within the same seed increases were remarkably similar in the different years as compared to the basic seed, these observations too can be regarded as dependable. Among the second-year observations the highest coefficients of variation were found for the number of headed stalks/plant and fresh weight; in terms of these two characteristics significant differences from the standard were only incidental. The 1969 trial produced some exceptionally low variation coefficients; this may have been due to the increased number of trial replications.

Correlations between the characteristics. All possible correlations between the different characteristics were calculated on the basis of the relative mean values for every experimental seed lot. It was found that for the different production locations the correlations between most of the characteristics studied turned out remarkably similar.

From the whole US material a highly significant negative correlation between the two characteristics indicating heading was obtained $\left(\mathrm{r}=-0.532^{* * *}\right)$; thus an increase in the percentage of plants headed in the first season clearly anticipated an early date of heading in the second. Neither of these was correlated with any of the other characteristics studied (very low and insignificant values of $r$ throughout) and they consequently can be regarded as independent of the others.

Of the second-year observations, and considering the whole material, it was found that winter survival, number of stalks, plant height and fresh weight were significantly and positively correlated with each other. Within each different location these characteristics were positively correlated as well, and the correlations were mostly significant or highly significant. Calculation of partial correlations showed that winter survival was most positively correlated with the number of stalks $\left(\mathrm{r}=0.716^{* * *}, \mathrm{r} * * *=0.469\right)$ and plant height $(\mathrm{r}=0.479 * * *)$, as was also the fresh weight $(\mathrm{r}=0.679 * * *$ and $\mathrm{r}=0.714 * * *$, respectively). The partial correlation between stalk number and plant height, on the other hand, was negative $\left(\mathrm{r}=-0.493^{* * *}\right)$. Between the four characteristics under study there 
were substantial and complicated interactions so that in these trials the characteristics, with the exception of winter survival, did not seem to meet particularly well the objectives of evaluation. This, on the other hand, offers at least a partial logical explanation of the somewhat varying results gathered from the observations on these characteristics (Fig. 5).

There were a few significant correlations only between the other pairs of characteristics, the most interesting of these being that between the proportion of prostrate-growing plants and winter survival $\left(\mathrm{r}=0.375^{*}\right)$.

\section{Forage production trials}

M e t h o d s. The changes in a plant cultivar caused by seed production outside the area of adaptation are most clearly and accurately demonstrated by single-plant evaluation trials; yet the true agricultural value of the seed lots produced under foreign conditions can only be shown by plot trials for forage production. For this purpose, forage production trials with Tammisto meadow fescue seed lots grown in the USA were established at Viik $\left(60^{\circ} 13^{\prime} \mathrm{N}\right)$ and Länsi-Hahkiala $\left(61^{\circ} 9^{\prime} \mathrm{N}\right)$ in South Finland in May 1968. Fresh forage yields were harvested in two subsequent years. The trial at Viik was arranged according to randomized block design with six replicates and $10.0 \mathrm{~m}^{2}$ plot size. At LänsiHahkiala, where two nitrogen levels (150 and $300 \mathrm{~kg} / \mathrm{ha} \mathrm{N}$ ) were included in the trial, a split-plot design was used with two replicates and $9.6 \mathrm{~m}^{2}$ plot size. The same seed lots were sown in both trials: basic seed 1966 from Tikkurila as standard, with the rest of the material consisting of American productions of 1967 (third generation from Prosser, fourth generation from Shafter and Tehachapi). Seeding rate was $20 \mathrm{~kg} / \mathrm{ha}$ of seed with $100 \%$ germination, row distance $15 \mathrm{~cm}$. Duncan's multiple range test was applied to the observation results and fresh yields. The dry matter and crude protein data were excluded from the statistical treatment as these determinations were not made on every replication.

$\mathrm{R}$ e s u l t s. It is known that in areas with low winter temperatures, such as Finland, heavy nitrogen dressing often causes substantial winter damage in grass cultivars of more southern origin. Therefore, when the effects of different nitrogen levels were studied, main interest was centered on winter survival of the stands. There were, however, no significant differences between the lots in either of the trials (Tables 13 and 14).

At Viik some minor changes in stand height were observed just before the first cut. It was of interest to note that at the same time the Shafter lot had the highest number of stalks per row meter. In the first harvest year it differed significantly from all the other lots, in the second year from the basic and Tehachapi lots. Thus the accelerated development of the material produced in Shafter became evident from forage trials as well as from the single-plant evaluation trials.

At Viik in both crop years the fresh yields of the first cut were slightly but insignificantly larger for the American lots than for the Finnish lot. In the second cut the lots from Prosser and particularly Shafter yielded less than the Finnish lot. The total fresh yields, however, were about the same for all the lots. In dry matter a slight increase in the first cut and a decrease in the second cut was found for the American lots, as compared with the basic lot. Differences in total crude protein yields were small; in both harvest years the Prosser and Shafter lots were slightly poorer in this respect than the rest of the lots tested. 


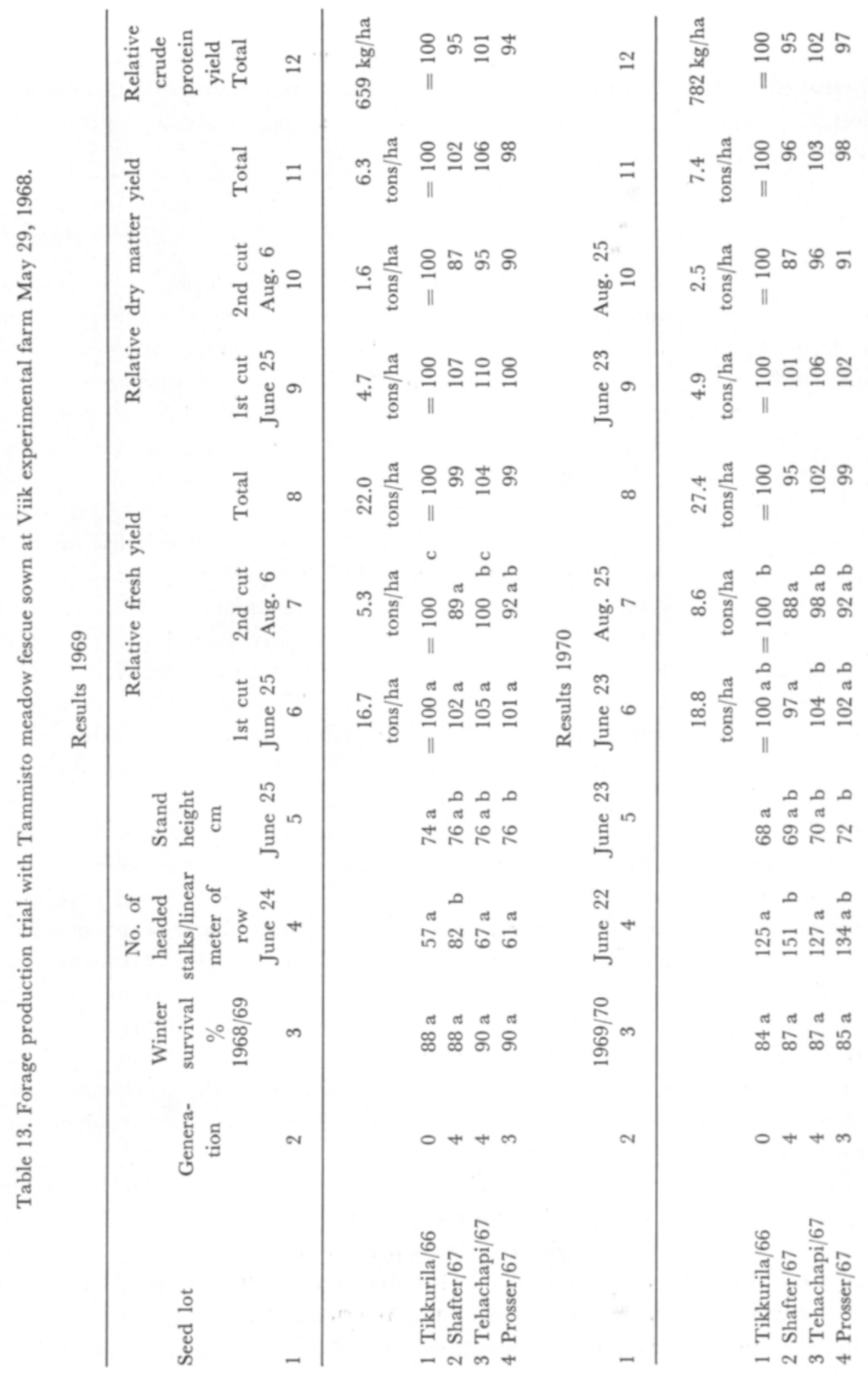




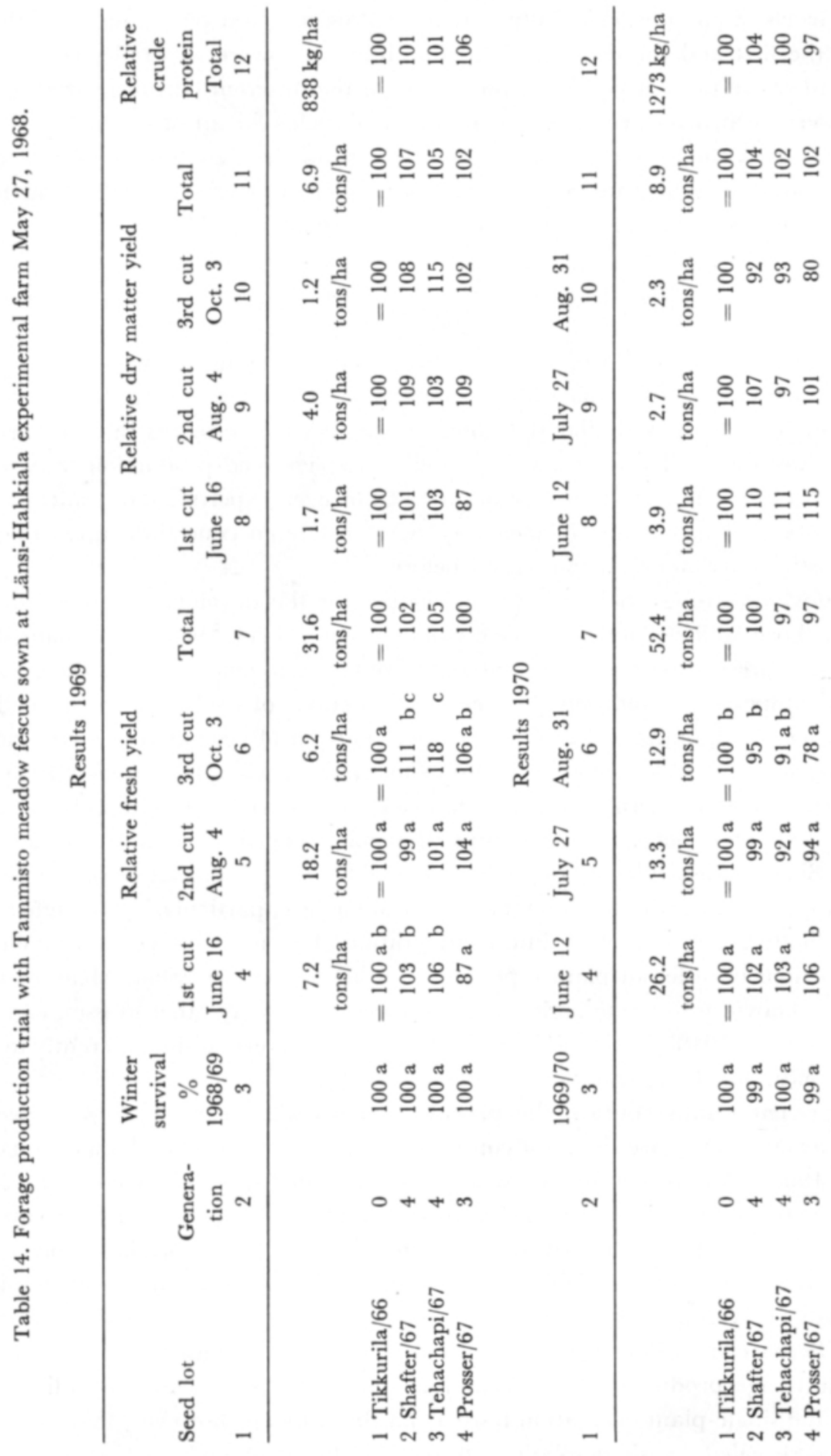


The trial at Länsi-Hahkiala was cut three times during the season. Since the number of replications was low, Table 14 presents the results for each cut as averages for both nitrogen levels. Some lots, especially that from Prosser, stood out in terms of their fresh yields at the first and the third cut, and the differences were also reflected in their dry matter and crude protein yields. In the course of the different cuttings variations within the lots were evened out, resulting in similar total yields for all of them.

The results of the two forage production trials show that seed production of the Tammisto meadow fescue in three or four successive generations in the USA had no detrimental effects on the agrinomical value of the cultivar.

\section{Discussion}

Seed multiplication of European grass cultivars including meadow fescue has increased under the O.E.C.D. scheme markedly in the USA and Canada during the 1960's (HoRNE 1966, PARnell 1966). A similar development has been in progress in Denmark, where conditions are especially favourable for foreign herbage seed production (SøndergaARD 1966). As far as is known to the present authors, however, experimental results concerning the effects of seed production of meadow fescue in foreign conditions upon the varietal characteristics have not been published before.

The obvious strong effect of photoperiodism on the development of graminaceous plants has been well documented (s e e CoOper 1960, Ryle 1966). The main shifts observed in the present experimental material may be partly explained by the great difference in photoperiodic conditions between the locations of seed production in the USA and the area of adaptation (Table 1). Seasonal pattern of vegetative growth and timing of heading usually show a close adaptation to the local climate (CoOPER 1963), which can be extended to concern also adaptation to local soil type, water supply and managements (Sonneveld 1966). In an attempt to explain why the Tammisto meadow fescue grown in Shafter was subjected to greater varietal changes than that grown in Tehachapi at virtually the same latitude, differences in local climate, particularly the higher temperature in Shafter, are to be taken into consideration. This may induce varying changes in the proportions of different plant types contributing to the seed yield. Meadow fescue as a species is known to tolerate higher temperatures than many other grasses, e.g. timothy (Hoover e t a 1. 1948), but its different climatic ecotypes react quite differently to extreme thermal conditions (COOPER 1968).

The present results confirm the previous experiences with other grass species that shifts in ear emergence are the most consistent indicators of varietal changes (s e e KELLY \& Boyd 1966). No correlations between earliness and fresh weight could be found in the present trials, which is in accord with the results from meadow fescue variety tests (Dent \& Aldrich 1963, Andonov 1969). In progeny tests a low correlation only has been shown in yield but a substantially higher one in earliness, between the single-plant and sward trials (FRANDSEN 1956). The same trend was obvious in the present trials.

No differences in winter survival or total yield could be indicated between the seed lots in the forage production trials, a finding that seems somewhat contradictory to the results of the single-plant evaluation tests. It has been found, however, that in swards the differences revealed by single-plant tests tend to become smaller (Copeman \& SwifT 
1966); this holds true in regard to winter-hardiness also (Cowling \& Kelly 1960). Moreover, substantially smaller shifts are likely to be registered in single-plant trials than in swards.

Certain reservations, however, are necessary in regard to the successful overwintering of the American-grown material in the present sward trials. It is possible that after an exceptionally severe winter and especially with a heavy nitrogen dressing, some real, significant overwintering differences between the lots might arise. In trials at Viik in 1966- 68 (unpublished results) some Danish meadow fescue cultivars presently under continuous successful cultivation in South Finland survived the severest winter seasons decidedly less well than the least successful American lots of Tammisto meadow féscue.

One of the reasons why in the present evaluation trials absolute shifts in the cultivar remained rather small is the fact that differences among long-day plants generally appear less conspicuous at northern latitudes than in the south.

Acknowledgments. The authors acknowledge the valuable contributions of Messrs. Clarence M. Rincker and John G. Dean, Research Agronomists, Plant Science Research Division, Agricultural Research Service, U.S. Department of Agriculture, Prosser, Washington; and Shafter and Tehachapi, California, respectively. Also we express our sincere gratitude to Professor Juhani Paatela, Department of Plants Husbandry, University of Helsinki, for his keen interest and continuous counsel during the course of these studies.

\section{REFERENCES}

Andonow, I. 1969. An inquiry into the relations between green-matter yields and earliness of earing in fescue grass (Festuca pratensis Huds.). J. Acta Univ. Agric. Brno, Fac. Agron. (A) 17: $63-69$.

Cooper, J. P. 1960. The use of controlled life-cycles in the forage grasses and legumes. Herb. Abstr. 30: $71-79$.

Cooper, J. P. 1964. Climatic variation in forage grasses. 1. Leaf development in climatic races of Lolium and Dactylis. J. appl. Ecol. 1: 45-62.

Cooper, J. P. \& TAInton, N. M. 1968. Light and temperature requirements for the growth of tropical and temperate grasses. Herb. Abstr. Rev. Article 38: 174-176.

Copeman, G. J. \& Swirt, G. 1966. The value of spaced plants in assessing the yield potential of herbage varieties at varying nitrogen levels. Proc. 10th int. Grassl. Cong. p. 263-267.

Cowling, D. W. \& Kelly, A. F. 1960. International co-operation for the classification of herbage varieties in Europe. Proc. 8th int. Grassl. Cong. p. 107-111.

Dent, J. W. \& Aldrich, D. T. 1963. The inter-relationships between heading-date, yield, chemical composition and digestability in varieties of perennial ryegrass, timothy, cocksfoot and medow-fecue. J. nat. Inst. agric. Bot. 9, 3: 261-281.

Frandsen, K. J. 1956. Progeny testing methods. Proc. 7th int. Grassl. Cong. p. 415-425.

Hoover, M. M., Hein, M. A., Dayton, W. A. \& Erlanson, C. O. 1948. The main grasses for farm and home. Orchardgrass, meadow-fescue, timothy. U.S. Dept. of Agric., Yearb. of Agric. 1948. p. $644-685$.

Horne, F. R. 1966. Technical developments in the operation of the O.E.C.D. herbage seed scheme. Proc. 10th int. Grassl. Cong. p. 761-765. 
Kelly, A. F. \& Boyd, M. M. 1966. The stability of cultivars of grasses and clovers when grown for seed in different environments. Proc. 10th int. Grassl. Cong. p. 777-782.

O.E.C.D. scheme for the varietal certification of herbage seed moving in international trade. 1968. Guide to the methods used in plot tests and to the methods of field inspection of herbage seed crops. AGR/T(68) 11. 34 p. Paris.

Parnell, H. R. 1966. Advancement of the O.E.C.D. herbage seed scheme in North America. Proc. 10th int. Grassl. Cong. p. 765-769.

Ryle, G. J. A. 1966. The influence of daylength on the growth of leaves and tillers in herbage grasses. Proc. 10th int. Grassl. Cong. p. $94-99$.

Sonneveld, A. 1966. Photoperiodic adaptation of grassland plants. Proc. 10th int. Grassl. Cong. p. $711-$ 714.

SendergaArd, E. 1966. Advancement of certified herbage-seed production in Denmark. Proc. 10th int. Grassl. Cong. p. $769-772$.

Valle, O. \& Carrison, C. S. 1963. International co-operation in the production of forage crop seeds. Am. Soc. of Agron. Food for Peace 1: $52-60$.

\title{
SELOSTUS
}

\section{USA:SSA SIEMENVILJELLYN TAMMISTON NURMINADAN OMINAISUUKSISTA}

\author{
Eero Valle, Otto Valle, Kirsti Äyräväinen \\ Helsingin yliopiston kasvinviljelytieteen laitos
}

\section{S. Garrison}

\section{Plant Science Research Division, Agricultural Research Service, U.S. Department of Agriculture}

Tammiston nurminadasta tuotettiin kolmella USA:n länsirannikon tutkimuspaikkakunnalla (Prosser, Washington sekä Tehachapi ja Shafter, Kalifornia) siementä neljässä perättäisessä polvessa. Suomessa pyrittiin yksilökokein selvittämään jokaisesta erästä, miten alkuperäalueen ulkopuolella tapahtunut siemenviljely vaikutti eräisiin maataloudellisesti tärkeisiin lajikeominaisuuksiin. Ensimmäiset yksilökokeet perustettiin Maatalouden tutkimuskeskuksen kasvinviljelylaitokselle Tikkurilaan sekä myöhemmät kokeet Yliopiston kasvinviljelytieteen laitokselle Viikkiin. Rehuntuotantokokein tutkittiin lisäksi eräiden kolmannen ja neljännen polven siemenerien viljelyarvoa.

Keskimääräiset siemensadot muodostuivat jokaisella USA:n tutkimuspaikkakunnalla runsaiksi (540$660 \mathrm{~kg} / \mathrm{ha}$ ), eikä siemenviljelypolvien lukumäärällä näyttänyt olleen mainittavaa vaikutusta sadon määriin. Keskimääräinen röyhyluku pinta-alayksikköä kohden jäi kuitenkin Shafterin viljelyksillä selvästi pienemmäksi kuin muilla paikkakunnilla.

Yksilökokeissa olivat muutokset Shafterin aineistossa suurempia perussiemenerään verrattuna kuin keskenään varsin samankaltaisissa Prosserin ja Tehachapin aineistoissa. Kunkin paikkakunnan ympäristöolosuhteiden valintapaine kuvastui täysitehoisena jo ensimmäisen korjuuvuoden siemenerien ominaisuuksissa, joissa todetut muutokset säilyivät samansuuruisina vastaavissa toisen korjuuvuoden erissä. Yksilökokeiden perusteella havaittiin selvimmät muutokset kasvien kehitysnopeudessa, sillä jokaisessa USA:ssa tuotetussa siemenerässä lisääntyi röyhylletulleiden yksilöiden osuus perustamisvuonna ja keskimääräinen röyhylletulopäivä oli toisena kasvukautena aikaisempi kuin verranteena käytetyn perussiemenen. Siirtymät aikaisempaa kehitystä kohden tapahtuivat suurimmalta osalta jo ensimmäisen polven siemenlisäyksissä. Edelleen todettiin, että aikaisuuden muutoksista saatiin näissä yksilökokeissa toisen kasvukauden havainnoista tarkempi kuva kuin ensimmäiseltä kaudelta. Muiden ominaisuuksien osalta muutokset olivat vähäisempiä ja erot perussiemeneen nähden vaihtelivat vuosittain suurestikin, lähinnä ilmeisesti kunkin kasvukauden sääoloista riippuen. Laakean kasvutyypin kasvien osuus kokonaispopulaatiosta USA:n 
aineistossa oli keskimäärin selvästi pienempi kuin perussiemenestä kasvatetussa aineistossa. Shafterin ja Prosserin kolmannen ja neljännen polven aineistossa havaittiin talvehtimisen heikkenemistä, sillä erot niin verranne- kuin ensimmäisen ja toisen polven aineistoon muodostuivat merkitseviksi.

Kokonaiskorrelaatiokertoimet yksilökokeiden eri havaintojen ja määritysten välillä osoittivat, koko USA:n aineistosta, erittäin markitsevän vuorosuhteen ensimmäisen ja toisen kasvukauden röyhylletulohavaintojen välillä. Toisaalta kumpikaan kyseisistä ominaisuuksista ei korreloinut minkään muun ominaisuuden kanssa, joten röyhylletulohavaintoja voitaisiin pitää erityisen sopivina lajikkeellisten muutosten indikaattoreina, kuten eräissä apila- ja heinäkasveja koskevissa tutkimuksissa onkin osoitettu. Käsiteltäessä kunkin siementuotantopaikkakunnan aineisto erikseen, todettiin yksilökokeissa merkitsevät positiiviset kokonaiskorrelaatiot seuraavien ominaisuuksien välillä: talvenkestävyys, röyhyluku/kasvi (2. kasvukausi), korkeus ja tuorepaino. Osittaiskorrelaatiokertoimet osoittivàt kuitenkin mainittujen ominaisuuksien liittyvän siinä määrin komplisoidusti toisiinsa, että näiden havaintojen avulla lienee vaikeaa selvittää lajikkeellisia muutoksia. - Länsi-Hahkialaan ja Viikkiin järjestetyt rehuntuotantokokeet osoittivat, ettei Tammiston nurminadan kolme-neljä polvea kestänyt siemenviljely USA:n länsirannikolla aiheuttanut haitallisia muutoksia lajikkeen talvehtimiseen ja rehuntuotanto-ominaisuuksiin. Shafterin aineistossa tosin todettiin, kuten yksilökokeissakin, röyhylletulon nopeutumista. 